\title{
Theorizing China-World Integration: \\ Sociospatial Reconfigurations and the Modern Silk Roads
}

Maximilian Mayer and Xin Zhang

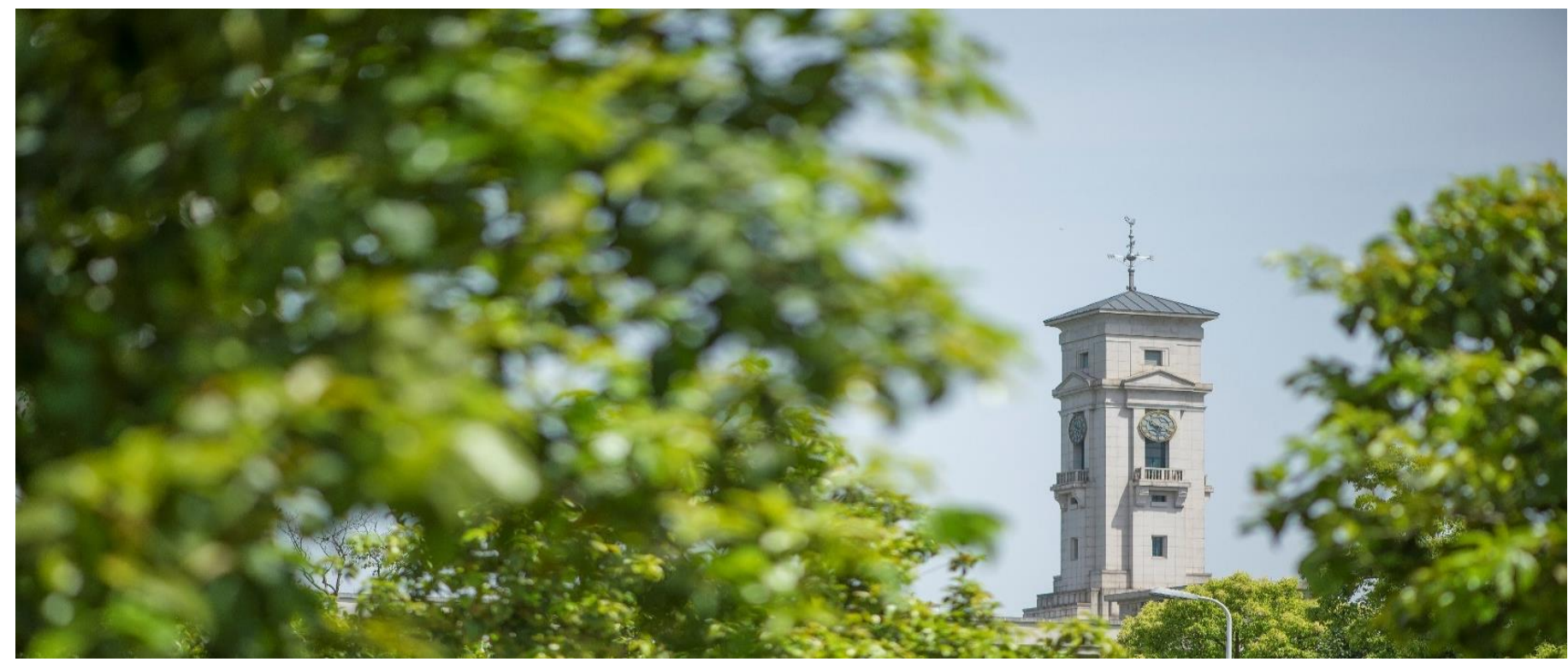


Faculty of Humanities and Social Science, University of Nottingham Ningbo China, 199 Taikang East Road, Ningbo, 315100, Zhejiang, China.

First published 2020

This work is made available under the terms of the Creative Commons Attribution 4.0 International License:

http://creativecommons.org/licenses/by/4.0

The work is licenced to the University of Nottingham Ningbo China under the Global University Publication Licence:

https://www.nottingham.edu.cn/en/library/documents/researchsupport/global-university-publications-licence.pdf 


\title{
Theorizing China-World Integration: Sociospatial Reconfigurations and the Modern Silk Roads
}

\author{
Maximilian Mayer and Xin Zhang
}

Maximilian Mayer, School of International Studies, University of Nottingham Ningbo China, maximilian.mayer@nottingham.edu.cn

Xin Zhang, School of Advanced International and Area Studies, East China Normal University, xzhang@ saias.ecnu.edu.cn 


\section{Abstract}

This paper develops a spatial perspective to examine the nature of China's transnational influence, focusing on the implications of the Belt and Road Initiative (BRI) for international relations. Drawing upon political economy, regional studies and critical geopolitics, we argue that the most interesting puzzle concerning the BRI pertains to the ongoing reconfigurations of political space. Contemporary sociospatial reconfigurations as analyzed through a multidimensional framework offer key insights into the operations and the extent of China's growing global power in general and with respect to the BRI in particular. We draw on a broad range of materials such as maps, Chinese academic and policy discourse as well as observations about corridor projects to theorize a) how the spatiality of global and regional connectivity is reconfigured through the process of China's integration with the world; and b) how corridorization as a dominant physical and ideational process shapes Chinese investment projects and reconfigures state spatiality along the BRI. The results indicate that the main territorial pattern is not the nation or the region but the corridor. Furthermore, expansionist and unidirectional stories of China's growing power overlook the local encounters and negotiations necessary for infrastructure projects to succeed. In addition, China's economic statecraft is contextualized within the ongoing post-financial crisis political-economic restructuring of territories, places, and scales within the global capitalist system.

Keywords: territorial rescaling, sociospatial structuration, Belt and Road Initiative, China, corridor, Euro-Asia 


\section{Introduction}

With over a $\$ 1$ trillion US dollar in promised investment and large-scale construction projects, the Belt and Road Initiative (BRI) has inspired a wealth of observations, research and disciplinary thinking about spatiality and space making (Jessop and Sum, 2018; Kuus, 2019; Narins and Agnew, 2019). ${ }^{1}$ Various popular interpretations of the BRI suggest crucial spatial implications either on a continental, regional or local scale. Geocultural, geoeconomic and geopolitical approaches to the BRI highlight how various formations of space underpinning political order are undergoing reconstruction as China is intensifying its relations with the rest of the world (Agnew, 2012; Ferdinand, 2016; Flint and Zhu 2019; Lin et al., 2019; Summers, 2016). Presumptions of larger-than-life investments clash with the realities of actual infrastructure projects, spurring heated debates about China's hegemonic ambitions and its alleged neocolonial approach (Blanchard and Flint, 2017; Nordin and Weissmann, 2018). Yet, a closer look at how Chinese infrastructure projects really affect the territorial configurations of states and economies on the ground leads to a more sober and nuanced understanding of the effects and limits of China's influence.

Exploring contemporary sociospatial reconfigurations offers key insights into the operations and extent of China's growing global power in general and the BRI in particular. Domestically, the reform and opening policy of the Chinese government has

\footnotetext{
${ }^{1}$ We wish to thank the anonymous reviewers and the editors of RIPE for their helpful comments. Previous versions of this paper have been presented at workshops at the University Nottingham Ningbo China and the National University of Singapore where we got invaluable feedback from participants. Thanks to Lewis Sanders for a helping hand with the language of this piece.
} 
used territorial rescaling and zoning techniques for decades, driving successful yet spatially uneven growth and development patterns. But, as much as the BRI's emerging set of sociospatial strategies builds on earlier experiences, it also entails a departure from the spatial thinking of both imperial China and the reform-era period while at times resembling neoliberal practices of 'state rescaling' (Brenner et al., 2003, pp. 7-9; Schindler \& Kanai, 2019). Taking a closer look at the recent explosion of novel representations of space within the Euro-Asian arena, we find that the Chinese state and investors respond to strong incentives to actively engage in a new 'spatial fix' both domestically and internationally. Such joint efforts aim at reconfiguring the geoeconomic vision driving Chinese capitalism in order to stimulate capital accumulation and expansion along a broader geographic scope ranging from the South China Sea to Europe and from East Africa to the Arctic. Importantly, the empirical reality of the BRI neither suggests that China is expanding its national territory as such; nor does it imply the redrawing of national borders of other countries. Instead, the role of space and scale for territorial organization, it seems, are newly imagined and reshaped in the context of the BRI across various regions.

A detailed look at China's economic statecraft generates critical insights into how China integrates with the rest of the world economically and politically and adds to the burgeoning scholarly interest in theorizing space making and forms of reterritorialization and rescaling across a variety of disciplinary fields. ${ }^{2}$ Our central research concern is to theorize, on the one hand, the ways in which BRI infrastructure projects influence the

\footnotetext{
${ }^{2}$ See special issues in International Affairs on maritime zoning (International Affairs 2019, Volume 95, Issue 5), in Geopolitics on politics of border (Geopolitics 2019, Volume 24, Issue 2), in Territory, Politics, Governance on metropolitan scales (Territory, Politics Governance 2018, Volume 6, Issue 2).
} 
sociospatial formation of states and economies. On the other hand, we examine the question to which novel ideas of territory, scale, and place the BRI is giving rise to while shaping an extended transnational project of envisioning state-society-economy futures. We articulate these issues through two questions: First, how are practices and imaginations of spatiality of global and regional connectivity reconfigured through the process of China's integration with the world? Second, how does the dominant physical and ideational spatial form of BRI investments - the corridors - reconfigure state spatiality along the BRI?

However, a series of considerations for this approach that must be considered beforehand. First, while the BRI is a state-driven project representative of a renewed emphasis on state-led investments and economic governance in China, it remains an open and evolving set of practices rather than a single grand strategy. Second, it needs to be stressed that the sociospatial restructuring within BRI countries and across regions is not simply imposed by Chinese agency. A key point here is that Chinese actors, while seeking their interests and contributing their development expertise and economic vision, inevitably have to tie into preexisting processes of spatial reconfiguration (cf. Easterling, 2014; Ong, 2004; Swyngedouw, 1997). The spatial reconfigurations related to the BRI are part and parcel of a multi-directional and historically evolving phenomenon of uneven integration and fragmentation (see Barbalet 2014; Tooze 2018; Turner 2007). Unidirectional stories of China's growing power, such as those told from a realist or geopolitical perspective, tend to gloss over the local encounters and negotiations necessary for Chinese infrastructure projects to succeed. In contradiction to the notion of 'China's rise' that permeates much of the IR literature, a spatial perspective advances the idea of 
China's global integration as a process of mutual apprehension and co-construction, contributing to a more adequate and powerful conceptual wager (Klinger and Muldavin 2019; Mayer 2018a).

In the remaining sections, we scrutinize the implicit spatial assumptions of geopolitical and geoeconomic approaches to the BRI. We then develop a conceptual framework that draws on the multidisciplinary body of research in regional studies, development planning and critical geography, especially drawing on the 'Territory-PlaceScale-Network' framework (Jessop et al., 2008). Empirically, our attempt to theorize China's effect on various dimensions of sociospatial restructuring is substantiated by a set of materials related to the BRI, including practices of knowledge production, map making, policy documents, academic discourse and ethnographic observations about effects of infrastructure projects—-focused on the China-Pakistan Economic Corridor (CPEC) and its similarities with other projects currently being developed under the umbrella of the BRI. The conclusion reconsiders China's global integration in light of contemporary spatial reconfigurations to suggest theoretical orientations for further cross-disciplinary research.

\section{The BRI and global processes of restructuring space}

First proposed by President Xi Jinping in 2013, and sketched out in subsequent speeches and policy documents, the BRI's two components - coined 'Silk Road Economic Belt' and '21st Century Maritime Silk Road' - form an organic approach aimed at reaching greater infrastructural and economic integration along the routes which link East Asia with Western Europe (National Development and Reform Commission, 2015). With an unusually grand scope and ambition, the Chinese government's ultimate goal is to connect 
East Asia, Central Asia, South Asia, Southeast Asia, Middle East and East Africa into a larger coordinated economic space. The BRI includes an array of new institutions such as the Asian Infrastructure Investment Bank (AIIB) and the Silk Road Fund, which are meant to facilitate the financing of large-scale infrastructure projects (Mayer, 2018a). Up until the end of 2019, China has signed cooperation agreements with more than 60 national governments and international organizations and held two major Belt and Road Forums in Beijing in 2017 and 2019. A range of key infrastructural projects across the Euro-Asian continent are under construction while, according to various media reports, further investments amounting up to $\$ 8$ trillion have been pledged (Hillan, 2018). When the $19^{\text {th }}$ Party Congress of the Chinese Communist Party (CCP) enshrined the BRI into the CCP's constitution in October 2017, it effectively became the umbrella for nearly all Chinese foreign policy. With the more recently proposed 'Polar Silk Road' and 'Space Silk Road', the Chinese government has extended the scope of the BRI even further (Huang, 2018; Sukhankin, 2018).

However, conflicting perspectives of the BRI exist. On the one hand, popular accounts claim that an economically-successful China is in the midst of reinstalling a Sino-centric order across Asia that updates the traditional tributary system (see Callahan, 2012; Howard, 2017). Such maneuvering could be viewed as the beginning of a new hegemonic cycle (Blanchard and Flint, 2017). On the other hand, scholars see the BRI's ultimate aim in establishing a great power sphere of influence to exclude the U.S. from the Eurasian landmass in order to counterbalance the U.S. 'pivot to Asia' (Flynt and Wu, 2017; Haider, 2017). Both perspectives suggest that the BRI is the most vivid expression of Beijing's challenge to the U.S.-led liberal world order. China, accordingly, is no longer 
viewed as a status quo power. Instead, it is seen as openly reshaping regional economic and political order in line with its own grand strategy (Tharoor, 2015, p. 2014) or-at the very least—establishing 'parallel' institutional arrangements that challenge existing international institutions (Heilmann et al., 2014; Nordin and Weissmann, 2018). These approaches - at times implicitly articulated - suggest a geopolitical reading of the BRI in that China's new geographical outlook is crucial for understanding the changing world order (Kaplan, 2019).

While such grandiose storylines are tempting, the real intricacies of the BRI suggest that power-based and overly state-centric narratives about China's new foreign policy fail to capture the transformative character of the BRI, especially in terms of remaking space and scale. For instance, the claim that China wants to form a 'neo-tributary' system runs against the complex and fractured cultural, security and institutional settings of local and regional infrastructure politics (Ford, 2010; Pan and Lo, 2017). Similarly, even though the BRI is animated by Beijing's push for a multipolar world order, its spatial dimensions cannot be reduced to a great chessboard where China counters the U.S. to break free from U.S.-led encirclement (Andornino, 2017; Overholt, 2015). Although the gigantic infrastructure investments of the BRI may boost China's soft power (Singh, 2016), it needs to be seen as part of a broader 'post-western' search for collective identity within China and across neighboring countries that stirs conflicting territorial claims and spatial visions beyond the control of the Chinese leadership (Mayer and Balázs, 2018; Y. Wang, 2016). Finally, the Chinese elites are relative newcomers to the 'Eurasian moment'. ${ }^{3}$ They opted for an open-ended approach that responds to and tries to coopt conflicting geographical imaginaries and histories of connectedness among political and economic

\footnotetext{
${ }^{3}$ For the concept of "Eurasian moment", please see Bordachev (2015) and Yang (2014).
} 
elites across the Eurasian landmass (Kaczmarski, 2017; Mayer, 2018b). In short, conventional geopolitical frameworks either overemphasize the strategic agency of a 'homogenized' China (Jones, 2019) or fall short of grasping the complex ways in which the BRI is embedded in multifaceted and multi-layered geopolitical processes.

The geoeconomic literature, instead of reducing the BRI to a grand design for achieving mastery over Asia, situates the initiative in the context of economic globalization and China's market integration (Breslin, 2013; Dent, 2016). From the vantage point of international political economy, the extensive scope of Chinese investments, political coordination efforts and developmental collaborations marks a new phase of economic statecraft which primarily springs from China's shifting domestic economic imperatives. Starting from a semi-peripheral status at the onset of the reform period in the late 1970s, China managed to integrate into international production chains with a tacit acknowledgement of the legitimacy of the U.S.-led liberal world order. However, three decades of overly aggressive capital accumulation within China has led to serious economic and social problems, including rising labor costs, rampant financial bubbles, large-scale social dislocation of migrant workers, increasing regional income disparity, and severe environmental degradation. As a result, the Chinese economy, since the late 1990s, exhibited a decreasing return on capital investments alongside increasing exposure to 'capital glut' and over-production (Arrighi, 2007; Hung, 2016).

Overcapacities have occurred in the financial, real estate, steel, cement, and construction sector among others (Zhang, 2017).

The signs of over-accumulation indicate a critical spatial juncture in Chinese capitalism: capital accumulation and expansion under the existing territorial limits of 
China's domestic market are no longer sustainable. Under such circumstances, as Harvey meticulously records, capital engages in a 'spatial fix' to resolve or at least temporally defer its inner crisis tendencies by geographical/spatial reorganization (Harvey, 2001a). Since the beginning of the $21^{\text {st }}$ century, there are intensified joint efforts between the Chinese state and different representatives of Chinese capital, even beyond major state firms, to further capital expansion overseas. For instance, the official 'go-abroad' policy announced in 1997 was the first major step taken by the Chinese state. The BRI is a much more comprehensive version of the go-abroad policy pursued against the background of growing economic imbalances, growing demand for resource and energy imports and difficulties to realize structural reforms domestically. Its mission to build hyperconnectivity across the Euro-Asian space and its advocacy for improved trade and financial integration is meant to facilitate the continuation of profit maximization for both private and state-owned enterprises in China.

The energetic and ambitious leadership of Chinese President Xi accelerated earlier political and financial tendencies. The year 2014 was a symbolic turning point, when China became a net capital exporting country. Between 2014 and 2018, Chinese companies invested more than $\$ 1$ trillion in about 1,700 projects across 130 nations according to data from American Enterprise Institute (Clifton and Dai, 2019). As Chinese outbound investments grew rapidly, her trade and investment policies increased the regional gravity of China's market economy (Yeh, 2016). The most visible parts of the BRI - the multiple layers of infrastructural constructions both over the land route and sea route along with other infrastructural facilities (such as dams, ports and special economic zones) — play a central role in providing specific spatial fixes at the regional level 
(Summers, 2016; Zhang, 2017). The official discourse puts emphasis on 'connectivity' and 'linkages' to such an extent that influential Chinese scholars interpret the initiative as an attempt to construct a China-led globalization in the form of 'the-world-is-connected' (Y. Wang, 2016), in contrast to the post-Cold War U.S.-led globalization in the form of 'the-world-is-flat' (Friedman, 2005).

The state-economy nexus at the core of the BRI's vision of logistical networks is however nothing specific to China. It is in fact in line with the historically central role state agency played in capitalism. Large-scale investments in infrastructures involve extremely long turnover time relative to all other forms of capital (Harvey, 1982, pp. 398405). The state is particularly well equipped to channel financial flows on this spatiotemporal scale for the planning and construction of "grand ensembles" of transport and urban infrastructures. Due to its capacity to allocate tax revenues and mobilize debtfinanced forms of investment as well as its regulatory control over the distinctive spatial configurations within which such investments are mobilized (Lefebvre, 1978, p. 238). While the state's centralized territorial form, as its most important defining feature, provides unrivaled leverage over resources and social forces (including capital, land, and labor) in order to restructure socioeconomic relations (Mann, 1984; Brenner et al., 2008, p. 8), the administrative organization at subnational levels evolves in a complicated relationship with the shifting geographic features and historical periods of capitalism (Harvey, 2001a). For instance, Chinese investments abroad in mineral extraction, timber and other natural resources are subject to the rapidly changing conditions of local extraction, trading practices and production networks operating within the world economy (Mohan and Urban, 2019; Summers, 2016). At the same time, economic interests and 
structural changes at the provincial level are crucial factors shaping China's external economic relations (Shahar and Lee, 2016; Summers, 2019; Xu, 2014).

But the economic statecraft inherent to the BRI also exemplifies the limits of a onedimensional or over-determined reading of the 'spatial fix' (see Jessop, 2006). As massive transport networks become territorialized and geographically immobile, one has to take even more serious the Chinese state's heterogeneous and shifting spatial strategies inside of global capitalism as a starting point to conceptually lodge the BRI within a historical process of changing domestic (and international) development strategies that apply varying models of territorial reconfiguration. As Schindler and Kanai (2019) argue, BRI investments are only one component of the 'global growth coalition' of banks, investors and international development organizations who are pushing for the construction of infrastructure and corridors — although China's economic size and investment largess as well as its specific state-economy nexus arguably renders the country the most significant actor. In collectively seeking new spatial arrangements - that is, 'getting the territory right' in response to over-accumulation and global financial instability - Chinese investors are among those who usher in a new phase of capitalist reterritorialization (Jiang, 2017; Park, 2014; Schindler and Kanai, 2019; Zhang, 2017). In Africa alone, for instance, there are more than 30 large corridor projects in planning or under construction and Chinese experts and companies have become involved in the build up of dozens of special economic zones (Bachmann et al., 2018, Luo, 2016). Furthermore, the infrastructure design, planning and investment by Chinese companies, physically connecting China's western provinces as well as metropolises with other regions and localities, remain conditioned by local and transnational processes that reshuffle the territorial and scalar 
constellations of economies, societies and administrations. As a result, Chinese

infrastructure projects such as trans-Himalayan highways and energy grids depend on the support of instable local coalitions. The renegotiations of financial debts from infrastructure projects, meanwhile, reveal that China's leverage even as a big donor is limited (Kratz et al., 2019; Murton and Lord, 2020).

China's economic statecraft needs to be analyzed, consequently, in the context of the ongoing post-financial crisis restructuring of political-economic organization of places and networks within the global capitalist system. This is possible by going beyond both assumptions of unidirectional power politics and mechanistic readings of 'spatial fixes'.

\section{A framework of sociospatial reconfiguration}

To examine the ways in which BRI projects influence spatial configurations requires a fine-grained conceptual framework. Building on the insights from a growing body of literature that analyzes the strategies, politics and (re)productions of space and scale (Bachmann, 2016; Brenner and Elden, 2009; Bulkeley, 2005; Jessop et al., 2008), we follow the comprehensive heuristic suggested by Jessop et al. (2008). Their TPSN framework integrates and interrelates four spatial principles/fields including territory (T), place $(\mathrm{P})$, scale $(\mathrm{S})$ and network $(\mathrm{N})$. Doing so enables 'a genuinely polymorphic mode of sociospatial analysis' (Jessop et al., 2008, p. 396) of the BRI and avoids a onedimensional analytical focus while offering three different yet interrelated conceptual lenses.

Territorializing — refers to creating and maintaining boundaries and borders in geographic space. Research at the intersection of sociology, critical geography/geopolitics, 
urban design, and international relations theory challenges territoriality as a pre-given and unchanging feature of inter-state relations. It addresses the evolving scalar organization of political-economic life in which the link between state, territory, economy, and sovereignty are socially and politically reproduced and periodically reconfigured (Brenner et al., 2003; Elden, 2009; Steinberg, 2001; Strandsbjerg, 2010; Thrift, 1996). Hence, while territory is not a fixed container naturally identical with the borders of national jurisdictions, space is seen as 'an outcome of territoriality, a human behavior or strategy' (Elden, 2010, p.756). Within the politico-geographical system established by Westphalian practices of state territoriality - state space in the narrow sense - states have mobilized a variety strategies for parceling, regulating, monitoring, and representing temporal and spatial borders (Agnew, 2005; Brenner et al., 2003). Similarly, geographical imaginations of the world are constitutive of territorial practices and their contestation. Geographers emphasize that cartographic materials are generative elements in geopolitical processes that redefine the scope, the functions, and boundaries of global territorial space (Harvey, 2001b; O Tuathail et al., 2006; Roberts, Secor, and Sparke, 2003). Maps are particularly relevant for the study of spatial imaginations because they are more than scientific representations of 'reality': they constitute a symbolic discourse that can mobilize dreams, aspirations, and worldviews (Agnew, 2003, p. 9; Callahan, 2009). Just as the territoriality of the modern state itself was a product of mapping and other scientific measuring practices to revise and reorganize space (Branch 2011; Crampton and Elden, 2006), we explore mappings and Chinese knowledge production about the BRI as relevant for the sociospatial reconfigurations implied by the BRI.

(Re)scaling states - is about the politics of reshaping the nested and hierarchical 
organization of political and regulatory authority according to new spatial forms. In a Marxist perspective, advanced particularly by Lefebvre, Harvey, and Brenner, the scalar configuration of state-space is subject to constant change and contestation because of contradictions between the fixity and motion of capital (Brenner, 1998a). On the one hand, capital strives to 'annihilate space through time' in its insatiable drive to expand and accumulate surplus value (Marx, 1973, p. 539) through overcoming all geographical barriers to its circulation process. On the other hand, to pursue this continual dynamic of ‘time-space compression' (Harvey, 1989a), capital necessarily depends upon relatively fixed and immobile infrastructures. During the cyclic changes of the capitalist world system, the processes of 'territorial rescaling' are crucial elements of state responses to economic globalization (Brenner, 1998b). More broadly, such a perspective emphasizes how global capitalist dynamics involving companies and states reshape scalar structures of administrative organization and infrastructures (Harvey, 2001b; Swyngedouw, 2004). Accordingly, new sites of state regulatory activity, rescaled both at sub- and supra-state levels, are established under conditions of rapid geo-economic change (Brenner et al., 2008; Sheppard and McMaster, 2004). For instance, to foster continuous growth, Chinese provincial and central governments combined scalar interventions and spatial planning to shape zoning strategies. Realizing a 'rapid spatial development and reconfiguration of China' (Lei and Shen, 2016), their goal was to effectively synchronize unevenly developed territories and places within national economies (local, urban and regional clusters) with transnational production chains and concentrated infrastructure-led capital accumulation (Fan, 1997; Lin, 2009; Mohan, 2013; Ong, 2004). In this vein, we examine the BRI as a process of (re)scaling of state space that can be observed unfolding on both 
supranational and subnational levels as it affects territory and places alike .

Producing places - is about the production and linkage of concrete sites and places.

Places do not only embody a 'historical layering of crystallized social relations' but are always 'produced' from nature through metabolic transformation (Swyngedouw, 2004, p.

131). In the context of the BRI, the sociotechnical relations characterizing places are mainly reshaped through the planning and construction of corridors (Mayer, 2018b). In light of the discussion above (Brenner, 1998a; Harvey, 2001a), the BRI can be conceptualized as a transnational process of implementing the corridor as peculiar 'scalar fix'. The concept of 'corridorization' grasps a flexible practice of territorial rescaling - not exclusively, yet especially in the context of Chinese foreign infrastructure investments. Hence, we explore the production of places as a consequence of rescaling territorial administrative practices and the reconfiguration — via infrastructure — of various places outside and inside of China into a network, in an attempt to create novel spatial relationships not only within the state unit but also across, between, and through territorial boundaries.

Analytically, we employ three spatial prisms (T, S, P) in a two-step approach to examine the sociospatial reconfiguration contained in the BRI. The next section studies a) the converging representations of global/continental connectedness as it is reflected in visions, anticipations, and representations as well as the Chinese knowledge production serving such a reconfiguration and b) how the spatiality of statehood is coproduced through local and transnational negotiations and alignments by zooming into the on-theground spatial organization, driven primarily by infrastructural projects of major economic corridors, in particular the CPEC to illustrate meso-level sociospatial reconfiguration. 


\section{Reconfiguring the spatial nature of China-World integration}

\section{Scales of China-World relations}

The ever-expanding scale contained in the BRI suggests new ways in which China structures its self-position vis-à-vis the world and through which scalar configurations China relates to the world. At the macro-level, shifting geographical imaginaries and presentations of space are a crucial element to understand the reconstruction of space, as new ideas, visions, and plans that affect world politics represent and visualize spatial configuration differently. Among the multiple spatial presentations of BRI, the most striking feature is the centrality of Eurasia, or more precisely, a Europe-Asia continent. The latter implies a spatial vision of China in the world in a manner very different from previous spatial visions held by either imperial China or early reform-period China.

Like other pre-modern empires, in its transition from empire to nation-state, China experienced an uneasy shift from pre-modern unbounded understandings of space and territory to bounded understandings of space and territory in the early twentieth century (Callahan, 2009). One major type of pre-modern vision for China, characterized by Fairbank (1968) as ‘concentric circles of increasing barbarity’, portrays ancient Chinese capital as the core, the primary tributary states as the closer circles and the final circles as the unknown 'Barbarian world'. Maps embodying such a vision do not represent a homogeneous space of equal sovereignty and legitimacy but rather a hierarchy of concentric circles with diminishing sovereignty from the imperial capital out to the periphery. As a result, 'imperial maps of China's domain are very detailed at the center but very vague at the margins, depicting an overall ambiguous and unbounded domain of 
empty or overlapping frontiers' (Callahan, 2009, p.149). Such spatial visions also differ from the single line boundaries that tended to define the sovereign territories of the Westphalian international system.

Recently, especially through the BRI, Chinese elites have come to perceive of 'Europe-Asia' as a holistic economic and moral unit. As the country's leadership has only focused on its immediate neighborhood for decades, China is a conceptual and intellectual latecomer when it comes to plans for the economic and infrastructural integration of greater Asia. For instance, up until the Hu Jintao era (2002-2012), the Chinese state's overall foreign policy orientation only extended from the major powers (US, Soviet Union and post-Soviet Russia) to the immediate neighboring countries (Lanteigne, 2008: chapters 6-7). Chinese elites had not developed a strategic vision for the Indian Ocean, nor for the entire Europe-Asia continent, let alone the region beyond China's immediate neighborhood.

But this situation changed with the BRI. A leading Chinese scholar on the New Silk Road presents the BRI as a fresh approach that 'signals China's active involvement in building a new trend of globalization, rather than only looking for opportunities to seek profits from it. It is China that is now promoting the integration of Eurasia' (Y. Wang, 2015). While Chinese and foreign observers debate whether the BRI is a 'Chinese Marshall Plan' (Curran, 2016; Ling, 2015), the Chinese government has articulated a comprehensive vision often dubbed 'China dream', which links China with almost all countries in Eurasia.

The process of geographic imagination still evolves and goes even continues to evolve, going beyond the Euro-Asian continent. Among Chinese academic and media 
circles, an un-official list of ' 65 countries along the Belt and Road' (yidayilu yanxianguo) has started to circulate after the 2015 'Vision and Actions' plan of BRI was released (Xinhua, 2017). These 65 countries on the list reflects what was stated in the 'Vision and Actions' plan that 'The Belt and Road Initiative aims to promote the connectivity of Asian, European and African continents and their adjacent seas, establish and strengthen partnerships among the countries along the Belt and Road' (National Development and Reform Commission, 2015). The list thus covers a continuous span of a large part of the whole Euro-Asian continent, plus Egypt. ${ }^{4}$ However, as more countries in Africa and Latin America, which are geographically non-contiguous with the Euro-Asian continent, signed official collaboration deals with China, the original unofficial 65-country list no longer made sense. Indeed, for its connotation of a finite number of countries 'along' a fixed 'belt and road', official sources never used this concept of 65-country. In official sources, Xi's statement at the 2017 Belt and Road Forum in Beijing further emphasized that the BRI 'focuses on the Asian, European and African continents, but is also open to all other countries. All countries from either Asia, Europe, Africa or the Americas, can be international cooperation partners of the Belt and Road Initiative' (Xi, 2017). Such expanding scale of geographic coverage of the BRI further illustrates the open, flexible, but also vague nature of the spatial vision underlying the BRI, which may go even beyond the Euro-Asian continent.

\section{Mapping the BRI's territory}

The maps that visualize the rhetoric of connectivity and connected dreams in BRI indicate a new spatial order. The repository of BRI maps we collected includes 39 maps prepared

\footnotetext{
${ }^{4}$ One map presenting the original list of $65 \mathrm{BRI}$ countries is available at Chin \& $\mathrm{He}(2016$, p. 1)
} 
by institutions and individuals based in mainland China and Hong Kong and 30 non-

Chinese renderings of the BRI, released between 2014 and $2018 .^{5}$ Although produced by different agents and for different audiences, the majority of these maps share many common features. As one can see from one representative BRI map, the vast Euro-Asian continent with parts of North Africa is presented in these BRI maps as an open, coherent, and malleable space, where national political boundaries and natural landscapes are portrayed in a very deemphasized manner. ${ }^{6}$ What official BRI documents and maps stress is the corridor as central territorial formation. Six large corridors are especially emphasized: the China-Mongolia-Russia Economic Corridor; New Eurasian Land Bridge; China-Central and West Asia Economic Corridor; China-Indo-China Peninsula Economic Corridor; China-Pakistan Economic Corridor; and Bangladesh-China-India-Myanmar Economic Corridor (National Development and Reform Commission, 2015). ${ }^{7}$ As a result, the Euro-Asian space is not only construed as such - as outlined in the section above - but also structured as a network of corridors that are supposed to facilitate 'connectivity, unimpeded trade, financial integration' (National Development and Reform Commission, 2015).

Flowing from the same logic, the locus of attention for the map-readers is instantly directed to the dots (manufacturing centers, transportation hubs, ports etc.), lines (transportation linkages) and stripes (corridors) in most of these BRI maps. As a result of blurry territorial or completely missing boundaries in these maps, statehood, sovereignty

\footnotetext{
${ }^{5}$ All these maps are available from the authors upon request.

${ }^{6}$ One such representative BRI map is available at http://www.cssn.cn/jjx/jjx_gdxw/201502/t20150210_1512135.shtml?COLLCC=563023871\&.

${ }^{7}$ One BRI map illustrating these 6 corridors is available at http://china-traderesearch.hktdc.com/business-news/article/The-Belt-and-Road-Initiative/The-Belt-and-RoadInitiative/obor/en/1/1X000000/1X0A36B7.htm.
} 
and fixed boundaries as the key defining features of the interstate system are downplayed (Narins and Agnew, 2019). Most BRI maps, whether produced by Chinese agencies or non-Chinese agencies, instead highlight linkages between hubs and cities. Many of them illustrate or highlight the networks and how space, not defined by traditional state boundaries, is structured through transnational corridors.

The territoriality suggested by BRI maps is strikingly different from historical Chinese maps. If in the early $20^{\text {th }}$ century one witnessed a transition from 'imperial domain's hierarchical unbounded space' to 'sovereign territory’s homogeneous bounded space' in the spatial vision of the Chinese elites (Callahan, 2009: 159), what has emerged with the BRI-related spatial representation can be called a 'homogenous unbounded space' across the Euro-Asian continent. As a result, the overlapping and multiple spaces reflected through BRI maps undermine the hegemonic understanding of modernist territorial sovereignty (see Agnew, 2010).

Finally, as a consequence of decentering old Europe and eclipsing the Americas, either Central Asia or the Indian Ocean move to the center stage in most of these BRI maps. Thus, the BRI territorial vision and spatial representation of the world challenges the long-held view about ancient Chinese self-understanding of their place in the world: China is not presented in these maps as the center of the world. At the same time, the boundaries and edges of these maps invoke - explicitly and implicitly — a Euro-Asia that is independent or cut off from its transatlantic and transpacific relations.

\section{Coproducing BRI places}

As projects such as ports, dams, roads, railways and industrial zones materialize, many places will be inevitably transformed. The (imaginary) sites to emerge from the BRI are 
no longer expected to have a peripheral economic nature. Official narratives downplay the traditional center-periphery dichotomy of the global economy. As such, the center of BRI is not necessarily limited to China and Europe. Through 'coordination' or 'docking' (duijie in Chinese) and the expansion of regions covered by the BRI, the alleged 'peripheral' regions and countries can all become regional centers in their own way (Zeng, 2015; H. Wang, 2016). In this sense, Chinese whitepapers, policy documents, and official speeches highlight the open and non-exclusive nature of the BRI, encouraging all countries along the BRI to develop their own 'Silk Road' plans. Through further integration of all these local 'Silk Road' plans, China and all connected countries are supposed to ultimately benefit from coordination and collaboration between these different plans $(\mathrm{Xi}, 2016)$. The Chinese state has openly declared plans to integrate similar regional economic integration plans proposed by, for instance, Russia, Kazakhstan, Mongolia, South Korea, Indonesia, and Malaysia, etc. with the BRI (Xia, 2017). Unlike Russia's Eurasian integration program, which spatially is more like continuously fencebuilding, Chinese economic statecraft follows the logic of a 'diffused' expansion. Beijing has not insisted on either binding state-to-state treaties or formal international institutions regarding the BRI, so as to maximize the flexibility and openness for both China and other countries involved in the BRI. ${ }^{8}$

Inspired by Harvey's theory of spatial fix and in the spirit of the Marxist idea of 'annihilation of space with time' (Harvey, 2001a; Marx, 1973), Chinese scholars define BRI as a practice of space-time compression, in particular, to exchange 'time' with 'space' (Jiang, 2015). In A study of the Spatial Strategy of Belt and Road Initiative, an early report

\footnotetext{
${ }^{8}$ Kaczmarski (2017) reaches a similar conclusion when comparing different regionalism embodied in the Eurasian Economic Union promoted by Russia and China's BRI.
} 
commissioned by the Ministry of Housing and Urban-Rural Development in 2015,

Chinese researchers explicitly advocated that BRI should help China reconfigure the spatial features of its development model. The influential report emphasizes the BRI's potential to reconfigure China's own regional development strategy to make use of 'full scale, all directional opening-up' as a way to facilitate comprehensive development of all major regions within China (China Academy of Urban Planning and Design, 2015). Earlier, China's regional development was characterized with significant regional unevenness and official policies emphasized the 'ladder-up' (tidu) nature of regional development, referring to the declining levels of factor endowments and economic development from the east and west of China. It was subsequently represented by the 'three economic belts' policy (sanda jingji didai) formulated in the Seventh Five-year Plan (1986-1990). These three belts are the eastern (coastal), central and western regions, with assigned specific roles that purportedly witnessed a reasonable sequence of economic development (Fan, 1997, p. 622; p. 624).

In response to such earlier regional development models, the BRI is expected to provide new opportunities to curb such a high degree of unevenness in development. The above-mentioned report reads: 'The transformation of world economic and trade framework and the ebb and flow of big power without exception all takes reconfiguration of domestic structures to handle the changes in the external situations. We need to modify China's internal spatial structures as to support the BRI in its smooth expansion' (China Academy of Urban Planning and Design, 2015). The report further specifies the construction of multiple corridors so that 'separation between the maritime and land routes, east-west division' will be transformed to 'comprehensive planning between the 
maritime and land Routes, balanced emphasis on East and West, thorough connection between the South and North' (China Academy of Urban Planning and Design, 2015), essentially putting an end to the 'three economic belts' policy. Through such endeavors, the report envisions each major domestic region corresponding to a transnational development zone/corridor.

\section{Knowledge production for a global China}

The Chinese state mobilizes its resources to actively promote specific knowledge and expertise that shapes and spreads the increasingly expanding scale of Chinese activities around the world. One key effort in this regard is the national-level 'MOE Project of Key Research Institute of Humanities and Social Sciences at Universities' set up by the Ministry of Education of the Chinese government (MOE) since 1999. These centers are regarded within the Chinese university system and research communities as the most influential and prestigious research hubs in the humanities and social sciences. Among these centers, eight were specifically devoted to area and country studies or international affairs. The selection of country/areas to be covered by these Key Research Institutes reflects certain preference in the Ministry's global geographic imaginary: three traditional major powers or regions (the United States, Europe, and Russia) along with four nearby regions or regional configurations (North-East Asia, Southeast Asia, South Asia, the Middle East). Such spatial and geographic vision resonates well with the general scalar orientation in China's foreign policy stance during the late 1990s: emphasis on big power politics and the nearby regions, with very limited reach to regions that are traditionally distant from China's home territory (Lanteigne, 2009, chapter 6). 
Since 2015, the Ministry of Education has started a new round of institutional building in university-based research centers, specifically to encourage and finance the establishment of 'Area and country research incubation centers'. The new list of nationally recognized centers is much more extensive (numbers of centers in parentheses): Africa (3), Arabic world (3), ASEAN/Southeast Asia (3), Latin America (2), South Asia (2), Central Asia (2), the Oceania (1), Eastern and Central Europe (1); US (2), Germany (2), Japan (2), France (2), Russia (2), Canada (2), UK (2). Overall, these centers provide comprehensive coverage of countries and regions around the world, including regions not geographically contiguous with China, such as Canada, Oceania, South Africa, Latin America, and the Arabic World. The new list is more spatially sensitive as it covers countries within a specific geographic area, such as Germany and France in Europe, Japan in East Asia/Asia Pacific. In the document, the Depart of Social Sciences of the MOE specifically stipulates the main goal for this plan is to 'provide intellectual support and talent guarantee for the reform projects of the state' (Ministry of Education, 2015).

In 2017, a different department (Depart of International Cooperation and Exchanges) of the MOE launched another round of institutional building specifically in the field of country and area studies, opening up registration of university-based centers for country and area studies. The goal of expanding the officially recognized university-based centers for country and area studies is to 'serve the state strategy and overall situation in foreign policy, fully promote the Belt and Road ... As the central leadership places high significance to this task, our department also enlists that as part of our key priorities for 2017 to further promote the countries and area studies and set a comprehensive coverage of all countries and regions in the world' (Ministry of Education, 2017). By the end of 
2018, the new series of university-based country and area studies centers registered with MOE included more than 400 centers based at more than 100 institutions of higher educations. These registered centers/institutes cover the 'supermajority' of countries and regions in the world (School for African Studies, 2018).

Through collective remapping Eurasia and the state-led construction of a globally oriented knowledge base to support the spatial expansion of China's foreign policy, China has presented a voice, for the first time in its modern history, to establish a global theme. Chinese elites now intentionally produce knowledge according to altered spatial parameters and imaginations. That is a sign that China is no longer trapped in 'oriental sinology' (Vukovich, 2012) and begins what Liang Qichao, the most prominent Chinese intellectual of the early 20th century, had envisioned as the last phase in China's three phases of global integration: from an ancient 'Unified China' to a medieval 'China of Asia' to the modern 'China of the World' (see Karl, 1998, p.1097). The ever-expanding scale of China's connectedness with the world should therefore be seen as the sociospatial reconfiguration of China's global connectivity: from 'China of Asia' to 'China of EuroAfro-Asia' and on the road to 'China of the World'. The question, then, is how such expanding scalar relations and related investments are productive of, and orchestrated through, an emerging network of infrastructural places in line with the contemporary territorial logic of global capitalism.

\section{Corridorization and the reconfiguration of state spatiality}




\section{Corridors as a spatial formation}

Corridors have become the key spatial idea driving development policies and investments in infrastructure globally. Traditionally, corridors were thought to consist of physical infrastructure and logistic hubs to connect centers of political power or production. Today, the rise of corridors is at the heart of a process of spatial restructuring and geographical reimagining. The corridor as structuring principle

'privileges cross-border connections and integration with global value chains (GVCs). The imperative of this emergent regime, as demonstrated by policy discourse and investment priorities, is to 'get the territory right' in order to attract foreign investment, foster industrial upgrading and export-oriented growth' (Schindler and Kanai, 2019, p. 2).

Corridors are intimately connected to an 'emergent regime of infrastructure-led development whose ultimate objective is to produce functional transnational territories that can be "plugged in"” to global networks of production and trade. Large-scale infrastructure projects such as railways, highways, dams, ports and regional power grids underpin comprehensive territorial development plans geared toward extracting resources, producing commodities, and moving goods to manufacturing facilities and finally to market' (Schindler and Kanai, 2019, p.1). In the context of the BRI, Chinese researchers define the corridor as 'an economic cooperation mechanism among different regions, built on transportation infrastructure. Economic corridors consist of three dimensions: infrastructure, urbanization and economic development' (Y. Wu, 2017, p. 68). 
The making of corridors should be defined as a sociospatial process — a 'spatial economic build-up ... defined as sub-regional economic cooperation mechanism that organically integrates production, investment, trade and infrastructural construction into one body within specific trans-national regional scale' (Liu and Lu, 2017, p.1). These reconstructions often necessitate transnational infrastructures crossing the limits of national jurisdictions and thus involving politics of scale as state spatiality is altered. Corridorization practices are part and parcel of the reterritorializing effects of global capitalism directed at the reorganization of administrations into variegated zones, exclaves of special jurisdiction, and layered border regimes (Bachmann et al., 2018; Mezzadra and Neilson, 2013).

China has adopted corridorization as a central spatial strategy to restructure its relations with nearby regions and across the Euro-Asian landmass. The official 2015 BRI document states the key goal of the BRI is to construct six major economic corridors along different directions, in a clearly all-inclusive, comprehensive manner. It reflects the abovementioned re-scaling practices of China's evolving visions and spatial strategies. Chinese researchers generally assume that economic corridors develop through four stages. The first stage is primarily focused on constructing transportation infrastructure. The second stage moves to urbanization and the revival of rural and urban infrastructure to facilitate industrialization and improve the investment environment for small-and-medium sized enterprises while enhancing investment in infrastructure for tourism and other sectors. Ultimately, the so-called regional development plan aims to expand the economic corridor. The third stage prioritizes facilitating the flow of goods, services, and personnel. The fourth stage focuses on coordinating various regional development plans and policies 
of different countries, to form the cross-border economic corridor in its real sense ( $\mathrm{Y}$. Wu, 2017, pp. 28-29). During this corridorization process the three dimensions of infrastructure building, urbanization and economic development are expected to proceed in parallel and mutually influence each other. Currently, BRI economic corridors rely predominantly on infrastructural building, especially transportation (Y. Wu, 2017, p. 29).

\section{Spatial state reconfiguration via corridorization}

The idea of building corridors as a scalar fix shares affinity with other spatial strategies used in China. Current practices of corridorization build on the country's development strategy pursued after 1978. Under the leadership of Deng Xiaoping, the party-state created special economic and administrative zones to link the isolated Chinese economy with the global trade system. Aiwa Ong's work on variegated types of sovereignty in Asia emphasizes that zoning was central to China's unique way of reterritorializing state space. According to Ong, the concept of 'Greater China', popular since the 1980s, consists of special economic and administrative zones that were aimed at integrating adjacent areas including Hong Kong, Taiwan, and Macao economically and politically (Ong, 2004, p.71). In the context of the emerging 'Pacific rim' economy, scholars have pointed out the importance of Chinese 'bamboo networks' for economic integration and investment activities in the Asia-Pacific region (Gao, 2003; Olds and Yeung, 1999). More recently, the Chinese state reformed the scalar institutional forms that govern city clusters and city regions within the Chinese administrative system in order to adapt to the changing logics of economic competition, production and labor markets (F. $\mathrm{Wu}, 2016)$. 
It becomes clear from this detour that the implementation of BRI projects follows a timetested range of state spatiality. Even though corridorization is at the core of the BRI, it corresponds and interlinks with other elements of a 'multi-spatial metagovernance' (see Jessup and Sum, 2017; Lee et al., 2017) that have territorial rescaling effects on administrative practices and the urbanization of regions outside China. The design of BRI exemplifies this logic: while its 'interconnectivity' policies do not challenge national sovereignty, they certainly promote transformations at the local or regional scale essentially following the logistics of international production networks, trade flows and energy supply (Lim, 2017; Summers, 2016). 'Belt Road Initiative', write Jessop and Sum (2017, p. 4), 'aims to constitute and (meta)govern relations among territories, places, scales and networks and to build trans-regional infrastructure, trading and commercial networks that link Eurasia and Africa.'

These corridors obviously are not imposed in an imperial style. Researchers who examine BRI- related processes of corridorization in different contexts - e.g. Murton and Lord (2019) on the Trans-Himalayan power corridors, Williams et al. (2019) with respect to global urbanization, and Akhter (2018) and Karrar (2019) on the China-Pakistan Economic Corrridor (CPEC) CPEC — conclude that the geographies of these corridors, their nodes, connections, intersections, and exclusions, are typically negotiated through preexisting political relations of various places and through complicated procedures and contestations. The infrastructural policies that link, for instance, Yunnan province in Southwest China with its neighboring countries illustrate the locally determined nature of promoting border-crossing links and reconfigurations of regional territoriality (Su, 2013). ${ }^{9}$

\footnotetext{
${ }^{9}$ Similarly, Chinese researchers claim that 'The Bangladesh-China-India-Myanmar economic corridor is buttressed by key transportation lines and combined transportation routes, take cities
} 
Meanwhile, broadly similar forms of corridorization are strongly pushed outside of the BRI too. ${ }^{10}$ The Asian Development Bank financed a series of studies to inquire the benefits of trans-border economic corridors in Southeast Asia, Central Asia and South Asia (De and Iyengar, 2014; Ministry of Finance, India, 2017). Partly set as projects competing with the BRI, Japan and India have envisioned similar corridors (e.g. the Asia Africa Growth Corridor) as joint international development projects across South Asia up to East Africa (The Research and Information System for Developing Countries, 2017).

\section{The China-Pakistan Economic Corridor}

During a state visit to Pakistan in April 2015, Chinese Premier Li Keqiang committed \$46 billion to fund energy and infrastructure projects in Pakistan over a decade. This announcement scaled up the already extensive presence of Chinese capital and expertise in Pakistan in multiple sectors, in particular the nuclear sector, hydropower, and highways (esp. the Karakoram Highway), and aimed to integrate CPEC into the larger BRI narratives. CPEC now is supposed to be 'closely related to the Belt and Road Initiative (BRI), and therefore requires closer cooperation and greater progress' (National Development and Reform Commission, 2015). Pakistani officials called the CPEC a 'fate changer' (The Nation, 2016).

With the start of construction works for railways and road networks, large portions of Pakistan are to be reconstructed as energy and transport corridors that stretch up

and ports (Kunming, Mandalay, Dhaka, Chittagong, Kolkata) as key knots/hubs, to facilitate connectivity and social economic development on sub-regional trans-national levels, which is meant to take energy transportation, trade, industrial cooperation and humanitarian communication as the key priorities. Its purpose is to align connections among economic and trade routes and development axis ("spindle") which connect Southwest China, Myanmar, Bangladesh, West Bengal of India, the east and Northeast part of India' (Liu and Lu, 2017, p. 1).

${ }^{10}$ For a discussion of on the notion of infrastructure corridors as spatial form of economic development see: Wilson and Bayón (2016);, Bouzarovski, et al. (2015), and Hildyard and Sol (2017). 
through northern Pakistan and into China's western provinces, thereby connecting China's landlocked Xinjiang with the port of Gwardar in Pakistan's Balochistan province. At the Indian Ocean near Pakistan's shared coastline with Iran, Gwadar is envisioned as a large port and Chinese window to the Arabian Sea. The CEPC also aims at rapidly globalizing Pakistan's sluggish economy and involves manufacturing zones, investments in agriculture, solar and coal power plants as well as large hydropower dams. It is expected to put an end to electricity shortages and boost Pakistan's development (CPEC Secretariat, 2017; Lieven, 2015). These flows of capital and expertise from China, first of all, constitute a networked production of space between China and Pakistan, intended to provide the conditions of capitalist accumulation within Pakistan and to integrate Pakistan into a larger Asian infrastructural space. As of late 2019, Pakistan's leaders claim that the CPEC is a model project for high quality collaboration for the construction of BRI (Xinhua, 2019).

Yet, while it was Islamabad that initially proposed to China to create an economic corridor (AFP, 2016), the undertaking causes concern among Pakistanis, ranging from debates about contested territorial claims, the uneven distribution of infrastructure, local terror attacks as well as a possible administrative and financial impasse (Ahmed, 2017). These concerns become intelligible through the lens of spatial reconfiguration, because 'one source of suspicion about CPEC stems from fears of constituencies within Pakistan of its deterritorializing potential' (Lim, 2017, p. 2). For one, Pakistan's national autonomy could be challenged by a growing Chinese presence and because of the legal and financial conditions of ownership and control over infrastructure. The size of investment alone makes it critical for Pakistan's financial sustainability. In addition to the initially proposed 
$\$ 46$ billion suite of investments in order to build the CPEC, Beijing pledged an additional $\$ 50$ billion to build several dams along the Indus River (Lieven, 2015; The New Indian Express, 2017). In short, the amount of CPEC-related infrastructure investments equal more than a third of Pakistan's annual GDP in 2016 (World Bank, 2017). This comes on top of the $\$ 24.3$ billion in official development aid and other official flows from China between 2000 and 2014.

Chinese investments mostly come in the form of loans backed by sovereign guarantees that place the eventual responsibility of covering all debts related to CPEC projects on Pakistani taxpayers (Aiddata, 2017). Although CPEC investments will be undertaken in tranches stretching over 20 years, China's domestic experience shows that the risk of defaults and underperforming infrastructure usage are huge (Ansar et al., 2016). While Pakistan needs significant economic progress in order to generate the revenues necessary to pay back interest and loans, Chinese companies involved in CPEC appear to be excluded from taxation and thus do not contribute to the fiscal base of the state. 'Pakistan,' notes a critical observer, 'risks losing its sovereignty and being beholden and exploited by China for its natural resources and geostrategic location' (Malik, 2017).

As far as security is concerned, CPEC-style corridorization involves an exclusive rescaling of security provisions that is contentious for its spatial effects and lack of fiscal transparency. The central government of Pakistan implemented a distinct governing structure to secure the construction of CPEC. For instance, given the insecure situation in tribal areas in Balochistan and the country's northwest region where local opposition against the CPEC is outspoken and at times violent, Pakistan's government deploys a 15,000-strong 'CPEC security force' in addition to a 'Gwadar Security Task Force' with 
the sole purpose of protecting infrastructure, Chinese workers and technicians (The Express Tribute, 2016; Zimmerman, 2016,). Pakistani media reported that the civilian government could not agree with the military about the range of authority the CPEP security force should command, as the former was concerned that it might 'expand military's influence on law enforcement agencies at the cost of civilian administration's authority' (Syed 2016). The employment of special forces also reinforces a segregated regime for the movement of persons. Although Chinese labor came into Pakistan (especially the northern regions) for building roads and dams, foreign experts and ecotourists who were moving freely in the Gilgit region lost access almost completely. In addition, many key sites of CPEC infrastructure are closed to Pakistani citizens for security reasons.

The military, which traditionally occupies a independent role in Pakistan, has become increasingly active throughout the CPEC spaces, adding to the economic burden and institutional messiness on the ground (Hussain, 2017). Beijing's increasing security and military cooperation with Pakistan's navy is first and foremost linked to CPEC (Baloch, 2017). The progressive securitization of critical infrastructure including ports, pipelines and roads tends to increase the instances of domestic borders and exclusion practices in Pakistan (Lim, 2017). The key actors for road, pipeline and dam construction are on both sides state-owned enterprises with close connections to the military or are run by military personnel. While this ensures ownership on both sides, Pakistani experts have questioned whether the CPEC deal has 'the necessary safeguards that will allow us to retain control of our territory if circumstances change' (Qureshi, 2015). 
India's government opposes Pakistan's territorial reconfigurations as it views its own territorial concerns directly affected by CPEC. In January 2017, Indian Prime Minister Narendra Modi - without mentioning the BRI by name - stated that 'connectivity in itself cannot override or undermine the sovereignty of other nations'. In a critical remark about corridors, Modi said that 'only by respecting the sovereignty of countries involved, can regional connectivity corridors fulfill their promise and avoid differences and discord' (The News, 2017). India's government primarily rejects CPEC because it runs through parts of Pakistani occupied Kashmir, which India claims to be part of its territory. The CPEC's rescaling of Pakistan northern territory via infrastructure construction is therefore not only perceived as generally increasing China's presence in the bilateral territorial conflict but also rendering these mountainous spaces official Pakistani territory (Kondapalli, 2017; Singh, 2015).

The grandiose idea to reconstruct large parts of Pakistan as a giant 'corridor' to link China's northwest region to the Indian Ocean is meant to create smooth logistical spaces through advanced transport and communication infrastructure. However, CPEC's spacesmoothing intentions have to confront the 'heterogeneous, fractured, and contradictory' social space in relation to the uneven regional distribution of political power over space, which generates tendencies towards the militarization of corridors and enclaves of logistical and infrastructural space (Akhter, 2017, pp. 235-236). Although the deemphasizing of national borders characteristic for BRI maps corresponds with the spatial practices and concerns of building the CPEC (Lim, 2017), the latter is not about 'expropriation' or 'expansion' of a Westphalian type territory. The ultimate consequences of an uneven modernization strategy that restructures scales and differentiations of state 
space in Pakistan remain unclear. As a key example of corridorization, the CPEC involves transnational bordering and parcelization or enclosure, somewhat similar to the earlier Chinese special economic zones. Meanwhile, it also heavily relies on place specific nodes and hubs (most notably the port of Gwardar) to create or reshape patterns of center and peripheral relations. For corridorization, the scale of sociospatial relations is usually zoomed in to a subnational-transnational level, creating a set of hierarchizations and vertical scalar divisions of labor that are different from a more horizontal spatial division of labor between traditional states.

Similar practices of transnational corridorization are taking place along the other five officially-designated economic corridors as part of the BRI. In addition, sociospatial reconfiguration via BRI corridors now includes attempts to connect non-adjacent regions. For example, the traditional subnational region-to-region collaboration between China and Russia has been heavily concentrated in the collaboration between Northeast China and the Russian Far East, two regions across the Sino-Russian borders. As such practices did not produce the expected results of promoting regional economic and social development, the Russian and Chinese states have started to push for novel sub-national regional cooperation. The primary example is the collaboration between the Middle and Upper Yangtze Region of China and Russia’s Volga Federal District, which started in May 2013. Even though the two regions are geographically distant and have little prior contact, as of late 2019, this non-adjacent sub-national 'corrdorization' such as the Volga-Yangtze format is regarded as successful policy innovation under the BRI's newly injected geographic visions (Liu, 2019, p.11). 


\section{Conclusion}

This article analyzes China's recent economic statecraft through the lens of sociospatial reconfigurations. We build on the "TPSN" framework in order to theorize how China's integration with the world reshapes the spatiality of global and regional connectivity and how the dominant physical and ideational spatial form of BRI investments - the corridor reconfigures state spatiality.

The BRI emerges through the interaction of state and capital in their convoluted relations of exerting and extending power, mastering and reconfiguring state space, through the practice of 'spatial fix' along multiple dimensions. The results constitute a new spatial vision, differing from both China's imperial model of 'concentric circles of civilization' and the 'greater China' model of the reform period. The BRI instead reflects a post-modern geopolitical condition of 'boundary-transgressing processes and tendencies that are undermining the state-centric assumptions of conventional geopolitics' (Tuathail, 2000: 166, see Agnew, 2003). These insights, while contributing to the new wave of infrastructure-centered research on the transformation of political order and territorial arrangements (Glass et al. 2019; Mayer and Acuto 2015; Neilson et al. 2018; Sassen 2019; Schouten et al. 2019), make one also cautious against overly simplifying interpretations that portray the BRI as an endeavor to realize Chinese regional or even global hegemony. Employing the concept of 'sociospatial reconfiguration' highlights that China's spatial practices such as the BRI are different from territorial expropriation or territorial expansion and conquest. Yet, the concept of sociospatial reconfiguration uncovers powerful and far-reaching effects of the BRI. The fresh geo-visions of most BRI maps contain a post-Westphalian, Euro-Asian landmass and replace the cartographic, and by extension political, centrality of the 'Atlantic world'. Though the implementation of the 
BRI is still in an early stage and might be slowed down due to China's sluggish economic growth and other problems, it ties into dynamics that could lead to a deeper integration of regions and countries across the Euro-Asian continent via markets and security institutions, further solidifying the Afro-Euro-Asian complex. As such, the geography of continents and connectivity imagined through the BRI differs from the earlier 'metageography' that arose during the Cold War (see Lewis and Wigen, 1997).

Our research shows that the BRI has strikingly neoliberal characteristics. The collection of maps demonstrates a near exclusion of bounded territory. Its spatial parameters seem to be reinforcing, in obvious contrast to the rise of populist protectionist ideologies in the West, preexisting tendencies of globalization. For instance, national borders remain underdetermined reflecting a constantly expanding scale of the new EuroAsian entity. The main territorial pattern is not the nation or the region but the corridor. BRI corridors have a regional/transnational scale and require concrete measures of administrative territorial rescaling such as illustrated in the case of the CPEC. The construction of subnational and transnational corridors creates new frontiers, boundaries and enclosures (social, economic, jurisdictional). New infrastructural linkages and nodal connectivity among concrete urban hubs across production chains also results in places and special economic zones repositioned in newly emerging core-periphery relationships. The related logistics of supply chain capitalism often connect, as Schouten et al. (2019, p. 289) emphasize, erstwhile marginal locations across 'fractured socio-political landscapes'. The political rhetoric of the BRI therefore helps to foster narratives promoting these depheripherizing moves. The resulting reconfiguration of state spatiality through multilayered, multi-scalar arrangements belies the easy division of 'domestic' and 
‘international' along traditional national boundaries (Easterling, 2014; Neilson, 2014). To encourage further comparative and historical work we draw on Philip Steinberg's work on maritime space to suggest that corridors belong to a new archetype instrumental to the sociospatial restructuring dynamics that underpin the BRI and beyond (Steinberg, 2001, pp. 41-67).

The BRI's heterogeneity and manifold local agency contradicts assumptions that foreground the grand schemes of geopolitics. As many countries, such as Myanmar, Sri Lanka, Nicaragua, Cambodia, Kenya, and Kazakhstan, experience similarly complex reconfigurations, corridorization in China's New Silk Road initiative has major implications for the re-imagining and re-making of both local and global space. But as China further integrates with the world, this study does not offer a comprehensive assessment of the multifaceted rescaling of state space. For instance, the differences between corridors are not conceptualized. Likewise, we have only gestured to the observation that although China is the most powerful player in the reconstruction of EuroAsian space, it is unable to simply craft a regional order through 'connectivity partnerships' or physical infrastructure. Future studies on spatial reconfiguration also need to pay attention to military activities as well as digital infrastructures that increasingly undergird the geopolitical competition between, among others, the US, India, Russia and China.

Studying the spatial aspects of the BRI is suggestive that merging IR and IPE frameworks is productive to exploring the dynamics of China's rise in general. Future research should focus on local responses to BRI projects and examine how negotiation processes generate enduring outcomes in the form of changing sociospatial structuration 
of states and economies. Methodologically, this requires a focus on territorial state transformation and a granular and empirically thick understanding of China's impact on dimensions of sociospatial restructuring (Hameiri, 2019; Klinger and Muldavin, 2019). Crucially, a spatial perspective reveals that China cannot easily translate its growing material power into transnational influence (over outcomes) and thus points to a classical IR puzzle. Despite billions spent on infrastructure projects, China cannot unilaterally impose new territorial forms along the Silk Road. Instead, Chinese actors find themselves in a sandwich position: on the one hand, negotiating with local interest constellations and, on the other hand, implementing capitalist sociospatial principles as part of a global coalition of investors and infrastructure developers. As a result, BRI projects ultimately remain embedded in processes that are only partially of China's own making. 
References:

Ahmed, M. (2017, March 14). CPEC: hopes and fears as China comes to Gwadar. Herald. Retrieved from http://herald.dawn.com/news/1153685.

AidData (2017). China's Global Development Footprint: the clearest look yet at Chinese official finance worldwide. Retrieved from http://aiddata.org/china.

AFP (2016, November 10). World Bank projects 5.4 per cent growth rate for Pakistan in 2018. Retrieved from https://www.dawn.com/news/1295477/world-bankprojects-54-per-cent-growth-rate-for-pakistan-in-2018.

Agnew, J. (1994). The Territorial Trap: the geographical assumptions of international relations theory. Review of International Political Economy, 1(1), 53-80.

Agnew, J. (2003). Geopolitics: re-visioning world politics (2nd ed.). London: Routledge.

Agnew, J. (2005). Sovereignty Regimes: territoriality and state authority in contemporary world politics. Annals of the Association of American Geographers, 95 (2), 437461.

Agnew, J. (2012). Looking back to look forward: Chinese geopolitical narratives and China's past. Eurasian Geography and Economics, 53 (3), 301-314.

Akhter, M. (2018). Geopolitics of the Belt and Road: Space, State, and Capital in China and Pakistan. In B. Neilson, N. Rossiter \& R. Samaddar (Eds), Logistical Asia: The Labour of Making a World Region (pp. 221-41). Palgrave Macmillan.

Andornino, G. B. (2017). The Belt and Road Initiative in China's Emerging Grand Strategy of Connective Leadership. China \& World Economy, 25 (5), 4-22.

Ansar, A., Flyvbjerg, B., Budzier A., \& Lunn, D. (2016). Does infrastructure investment lead to economic growth or economic fragility? Evidence from China. Oxford Review of Economic Policy, 32 (3), 360-390.

Arrighi, G. (2007). Adam Smith in Beijing: Lineages of the twenty-first century. London: Verso.

Nordin, A.H. M., \& Weissmann, M. (2018). Will Trump make China great again? The belt and road initiative and international order. International Affairs, 94 (2), 231249.

Bachmann, V. (2016). Spaces of interaction: enactments of sociospatial relations and an emerging EU diplomacy in Kenya. Territory, Politics, Governance, 4 (1), 75-96.

Bachmann, J., Knutsson, P., \& Musembi, B. (2018, August). What does a STS perspective add to the study of development corridors? Paper presented at the Swedish Development Research Conference, Gothenburg, Sweden.

Baloch, B. (2017, January 16). China Hands Over Two Ships to Pakistan for Maritime Security. Dawn. Retrieved from https://www.dawn.com/news/1308491.

Benton, L. (2009). A Search for Sovereignty: law and geography in European empires, 1400-1900. Cambridge, UK: Cambridge University Press.

Blanchard, J-M. (2017). Probing China's Twenty-First-Century Maritime Silk Road Initiative (MSRI): an examination of MSRI narratives. Geopolitics, 22 (2), 246268.

Blanchard, J-M., \& Flint, C. (2017). The geopolitics of China's maritime silk road initiative. Geopolitics, 22 (2), 223-245.

Barbalet, J. (2014). Globalization and Cosmopolitanism: Continuity and disjuncture, contemporary and historical. Journal of Sociology, 50 (2), 199-212. 
Bordachev, T. (2015). New Eurasian Momentum: how to make integration effective. Russia in Global Affairs, 14 December.

Bouzarovski, S., Bradshaw M., \& Wochnik, A. (2015). Making Territory through Infrastructure: The Governance of Natural Gas Transit in Europe. Geoforum, 64, 217-228.

Branch, J. (2011). Mapping the Sovereign State: technology, authority, and systemic change. International Organization, 65 (1), 1-36.

Breslin, S. (2013). China and the Global Political Economy. London: Palgrave.

Brenner, N. (1998a). Between Fixity and Motion: accumulation, territorial organization and the historical geography of spatial scales. Environment and Planning D: Society and Space, 16 (4), 459-481.

Brenner, N. (1998b). Global Cities, Glocal states: global city formation and state territorial restructuring in Contemporary Europe. Review of International Political Economy, 5(1), 1-37.

Brenner, N., and Elden, S. (2009). Henri Lefebvre on state, space, territory. International Political Sociology, 3 (4), 353-377.

Brenner, N., Jessop, B., Jones, M., \& MacLeod, G. (2003). Introduction: state space in question. In N. Brenner, B. Jessop, M. Jones, \& G. MacLeod (Eds), State/space: A Reader (pp.1-26). Malden, MA: Blackwell Publishing.

Bunnell, T., \& Coe, N. M. (2005). Re-fragmenting the 'political': globalization, governmentality and Malaysia’s multimedia super corridor. Political Geography, 24 (7), 831-849.

Callahan, W. A. (2008). Chinese Visions of World Order: post-hegemonic or a new hegemony? International Studies Review, 10 (4), 749-761.

Callahan, W. A. (2009). The Cartography of National Humiliation and the Emergence of China's Geobody. Public Culture, 21 (1), 141-173.

School for African Studies (2018). Conference Minutes of the $4^{\text {th }}$ National Conference on MOE Country and Area Studies Registered Centers. Retrieved from http://ias.zjnu.cn/2018/1119/c6404a274049/page.htm.

Chin, H. \& He, W. (2016). The Belt and Road Initiative: 65 Countries and Beyond. Fung Business Intelligence Centre.

China Academy of Urban Planning and Design (2015). Yidaiyilu kongjian zhanlue yanjiu [A study of the Spatial Strategy of Belt and Road Initiative].

Clifton, J. and Dai, S. (2019, October 2). China's outbound investments have hit a snag, but its M\&A in Asia and Oceania show it's still the face of globalization. South China Morning Post. Retrieved from https://www.scmp.com/comment/opinion/article/3031116/chinas-outboundinvestments-have-hit-snag-its-ma-asia-and-oceania.

CPEC Secretariat (2017). Introduction, China Pakistan Economic Corridor. Retrieved from http://cpec.gov.pk/introduction/1.

Crampton, J. W. \& Elden, S. (2006). Space, politics, calculation: an introduction. Social \& Cultural Geography, 7 (5), 681-685.

Curran, E. (2016, August 8). China's Marshall Plan. Bloomberg. Retrieved from https://www.bloomberg.com/news/articles/2016-08-07/china-s-marshallplan. 
De, P., \& Iyengar, K. (Eds.). (2014). Developing Economic Corridors in South Asia. Manila: Asian Development Bank.

Dent, C. M. (2016). East Asian Regionalism (2nd ed.). London: Routledge.

Derian, J. (1990). The (S)pace of International Relations: simulation, surveillance, and speed. International Studies Quarterly, 34 (3), 295-310.

Dirlik, A. (2007). Global Modernity: modernity in the age of global capitalism. Boulder: Paradigm Publishers.

Easterling, K. (2014). Extrastatecraft: the power of infrastructure space. London: Verso.

Edwards, P. N. (1997). The Closed World: computers and the politics of discourse in Cold War America. MA: MIT Press.

Elden, S. (2009). Terror and Territory: the spatial extent of sovereignty. Minneapolis: University of Minnesota Press.

Elden, S. (2010). Thinking Territory Historically. Geopolitics, 15 (4), 757-761.

Emerson, M., and Vinokurov, E. (2009). Optimisation of Central Asian and Eurasian Trans-Continental Land Transport Corridors. EUCAM Working Paper, No. 7.

The Express Tribute (2016, December 14). Task Force-88: Navy raises force for CPEC, Gwadar security. Retrievd from https://tribune.com.pk/story/1262606/task-force88-navy-raises-force-cpec-gwadar-security/.

Fairbank, J. K., (Ed.) (1968). The Chinese World Order: traditional China's foreign relations. Mass.: Harvard University Press.

Fan, C. C. (1995). Of belts and ladders: state policy and uneven regional development in post-Mao China. Annals of the Association of American Geographers, 85 (3), 421449.

Fan, C. C. (1997). Uneven Development and Beyond: Regional Development Theory in Post-Mao China. International Journal of Urban and Regional Research, 21 (4), 620-639.

Ferdinand, P. (2016). Westward ho-the China dream and "one belt, one road": Chinese foreign policy under Xi Jinping. International Affairs, 92 (4), 941-957.

Flint, C., \& Zhu C.P. (2019). The geopolitics of connectivity, cooperation, and hegemonic competition: The Belt and Road Initiative. Geoforum, 99, 95-101.

Flynt, L. \& Wu, B. B. (2017). The New Silk Road and China's Evolving Grand Strategy. The China Journal, 77, 110-132.

Foucault, M. (2007). Territory, Security, Population: lectures at the Collège de France, 1977-1978. Trans. G. Burchell. New York: Palgrave Macmillan.

Ford, C. A. (2010). The Mind of Empire: China's history and modern foreign relations, Lexington: University Press of Kentucky.

French, H. W. (2017). Everything under the Heavens: how the past helps shape China's push for global power. New York: Alfred A. Knopf.

Friedman, T. L. (2005). The World is Flat: a brief history of the twenty-first century. New York: Farrar, Straus and Giroux.

Gao, T. (2003). Ethnic Chinese networks and international investment: evidence from inward FDI in China. Journal of Asian Economics, 14 (4), 611-629.

Gakunu, P., Demissie, A., Weigel, M., Zhuo, K., \& Li, L. (2015) 'If Africa builds nests, will the birds come? Comparative Study on Special Economic Zones in Africa and China', Working Paper Series No.6, UNDP. 
Guo, L.Q. (2015, January 21). Shangwubu: 2014 nian zhongguo yijing chengwei ziben jingshuchuguo' [Ministry of Commerce: China in effect has already become a net capital-exporting country in 2014]. Diyi Caijing. Retrieved from http://www.yicai.com/news/4066035.html.

Haider, Z. (2017, May 23). Can the U.S. Pivot Back to Asia? How Trump should respond to China's Belt and Road Initiative. Foreign Affairs. Retrievd from https://www.foreignaffairs.com/articles/china/2017-05-23/can-us-pivot-back-asia.

Hameiri, S., \& Jones, L. (2016). Rising powers and state transformation: the case of China. European Journal of International Relations, 22 (1), 72-98.

Harvey, D. (1982). The Limits to Capital. London: Verso.

Harvey, D. (2001a). Globalization and the 'Spatial Fix'. Geograhische Review, 2(3), 2330.

Harvey, D. (2001b). Cartographic identities: geographical knowledges under globalization. In D. Harvey (Ed), Spaces of Capital: Towards a Critical Geography (pp. 208-33). Edinburgh: Edinbergh University Press.

Harvey, D. (2006). The Sociological and Geographical Imaginations. International Journal of Politics, Culture, and Society, 18 (3), 211-255.

Heilmann, S., Rudolf, M., Huorati, M., \& Buckow, J. (2014). 'China's Shadow Foreign Policy: Parallel Structures Challenge the Established International Order', China Monitor, Mercator Institute for China Studies.

Hildyard, N., and Sol, X. (2017). How infrastructure is shaping the world: a critical introduction to infrastructure mega-corridors. Brussels: Counter Balance.

Hillan, J. E. (2018, April 3). How big is China's Belt and Road? CSIS Commentary. Retrived from https://www.csis.org/analysis/how-big-chinas-belt-and-road.

Huang, E. (2018, June 18). China is building its new Silk Road in space, too. Quartz. Retrieved from https://qz.com/1276934/chinas-belt-and-road-initiative-briextends-to-space-too/.

Hung, H-F. (2016). The China Boom: why China will not rule the world. New York: Columbia University Press.

Hussain, K. (2017, January 5). Hidden Costs of CPEC. Dawn. Retrieved from https://www.dawn.com/news/1286698/hidden-costs-of-cpec.

Jiang, Z.D. (2015). 'Yidaiyilu': yi 'kongjian' huan 'shijian' de fazhan zhanlue' [One Belt and One Road: a development strategy of exchanging 'time' with 'space'], Heping yu Fazhan [Peace and Development] 4, 1-11.

Jessop, B. (2006). Spatial fixes, temporal fixes and spatio-temporal fixes. In N. Castree \& D. Gregory (Eds), David Harvey: A Critical Reader (pp.142-166). Blackwell: Oxford.

Jessop, B. (2016). Territory, politics, governance and multispatial metagovernance. Territory, Politics, Governance, 4(1), 8-32.

Jessop, B., Brenner, N., \& Jones, M. (2008). Theorizing sociospatial relations. Environment and planning D: society and space, 26 (3), 389-401.

Jessop, B., \& Sum, N-L. (2018). Geopolitics: Putting geopolitics in its place in cultural political economy. Environment and Planning A: Economy and Space, 50 (2), $474-$ 478. 
Jones, L. (2019). Does China's Belt and Road Initiative Challenge the Liberal, RulesBased Order? Fudan Journal of the Humanities and Social Sciences, 13 (1), 113 133.

Kaczmarski, M. (2017). Non-western visions of regionalism: China's New Silk Road and Russia's Eurasian Economic Union. International Affairs, 93 (6),1357-1376.

Kaplan, R.D. (2019). The Return of Marco Polo's World: War, Strategy, and American Interests in the Twenty-first Century. Random House.

Karl, R. E. (1998). Creating Asia: China in the World at the Beginning of the Twentieth Century. The American Historical Review, 103 (4), 1096-1118.

Klinger, J. M., \& Muldavin, J. S.S. (2019). New Geographies of Development: Grounding China's Global Integration. Territory, Politics, Governance, 7 (1), 1-21.

Kondapalli, S. (2017). 'Why India is not part of the Belt and Road Initiative summit', The Indian Express, 15 May.

Kratz, A., Feng, A., \& Wright, L. (2019, April 29). New Data on the 'Debt Trap' Question. Rhodium Group. Retrieved from https://rhg.com/research/new-data-onthe-debt-trap-question/.

Kuus, M. (2019). Political geography III: Bounding the International. Progress in Human Geography. doi:10.1177/0309132519869457

Lanteigne, M. (2008). China's Maritime Security and the 'Malacca Dilemma'. Asian Security, 4 (2), 143-161.

Lanteigne, M. (2009). Chinese Foreign Policy: an introduction. London: Routledge.

Lee, S-O., Wainwright, J., \& Glassman, J. (2017). Geopolitical economy and the production of territory: the case of US-China geopolitical-economic competition in Asia. Environment and Planning A: Economy and Space A, 50 (2), 416-436.

Lefebvre, H. (1978). Space and the State. In N. Brenner \& S. Elden (Eds), State, Space, World: selected essays, translated by G. Moore, N. Brenner, \& S. Elden (pp. 223253). Minneapolis: University of Minnesota Press,

Lefebvre, H. (1991). The Production of Space, translated by D. Nicholson-Smith, Cambridge, Mass: Blackwell.

Lewis, M.W., \& Wigen, K.E. (1997). The Myth of Continents. A Critique of Metageography. Berkeley: University of California Press.

Lieven, A. (2015, November 16). The China-Pakistan Corridor: A Fate-Changer? Aljazeera. Retrieved from http://www.aljazeera.com/indepth/opinion/2015/11/china-pakistancorridor-fate-changer-151111080012375.html.

Lin, G.C.S. (2009). Scaling-up Regional Development in Globalizing China: Local Capital Accumulation, Land-centred Politics, and Reproduction of Space. Regional Studies, 43(3), 429-447.

Lin, S., Sidaway, J.D., and Woon, C. Y. (2019) Reordering China, Respacing the World: Belt and Road Initiative (一带一路) as an Emergent Geopolitical Culture. The Professional Geographer, 71 (3), 507-522.

Ling, J. (2015, June). The "New Silk Road" Initiative: China's Marshall Plan? China Institute of International Studies. Retrieved from http://www.ciis.org.cn/english/2015-06/11/content_7982914.htm.

Lim, A. C-H. (2017). The Moving Border of the China-Pakistan Economic Corridor. Geopolitics, 24 (2), 487-502. 
Liu, J. (2019). 'Zhong'e “changjiang-fuerjiahe' diqu hezuo zhong de touzi kunjing yanjiu' [A study on the investment dilemma in the regional cooperation between "Yangtze River and Volga River Region" between China and Russia] Eluosi Dongou Zhongya Yanjiu [Journal of Russian, Eastern European and Central Asian Studies], 2, 110-122.

Liu, Z., \& Lu S. G. (2017). Mengzhongyinmian jingji zoulang jianshe de lilun yu shijian [The theories and practices of construction of the Bangladesh-China-IndiaMyanmar Economic Corridor]. Beijing: Social Science Literature Press.

Luo, H. (2016). Report on the Development of Africa's Special Economic Zones. In Y. Tao \& Y. Yuan (Eds), Annual Report on the Development of China's Special Economic Zones (pp. 281-302). Singapore: Springer.

Mezzadra, S., \& Neilson, B. (2013). Border as Method, or, the Multiplication of Labor. Durham: Duke University Press.

Malik, A. (2017, January 4). Pakistan Risks Losing Sovereignty to China with Its CPEC Gamble. Dailyo. Retrieved from http://www.dailyo.in/politics/cpec-chinapakistan-gwadar-port-economic-corridor-balochistan/story/1/14896.html.

Mann, M. (1984). The Autonomous Power of the State: Its Origins, Mechanisms and Results. European Journal of Sociology, 25 (2), 185-213.

Marx, K. (1973) [1857] The Grundrisse: foundations for the critique of political economy. Translated by Martin Nicholas. New York: Vintage Books.

Mayer, M. (2018a). China's Rise as a Eurasian Power: The Revival of the Silk Road and Its Consequences. In M. Mayer (Ed), Rethinking the Silk-Road: China's Belt and Road Initiative and Emerging Eurasian Relations (pp. 1-42). London: Palgrave.

Mayer, M. (2018b). The Return of History and China's Historical Statecraft. International Affairs, 94 (6): 1217-1235.

Mayer, M., \& Balázs, D. (2018) Modern Silk Road Imaginaries and the Co-production of Space. In M. Mayer (Ed), Rethinking the Silk Road: China's Belt and Road Initiative and Emerging Eurasian Relations (pp. 205-226). London: Palgrave.

Ministry of Education, China (2015, January). Announcement of the regulatory rules for Country and Area Research Bases. Retrieved from http://www.moe.gov.cn/srcsite/A20/s7068/201501/t20150126_189316.html.

Ministry of Education, China. (2017, March). Notice on Improving the Work on Country and Area Researches. Retrieved from http://www.moe.gov.cn/srcsite/A20/s7068/201703/t20170314_299521.html.

Ministry of Foreign Affairs, China (2014, September 17). Xi Jinping and President Mahinda Rajapaksa of Sri Lanka Jointly Inspect China-Sri Lanka Port Cooperation Project, Promoting the Construction of the 21st Century Maritime Silk Road. Retrieved from https://www.fmprc.gov.cn/mfa_eng/topics_665678/zjpcxshzzcygyslshdsschybdtjks tmedfsllkydjxgsfw/t1192787.shtml.

Ministry of Finance, India (2017). Economic Corridor Development (ECD) now at the forefront in promoting Sustained Growth in the SASEC Sub-region. Retrieved from http://pib.nic.in/newsite/PrintRelease. aspx?relid=159935.

Mohan, G. (2013). Beyond the enclave: Towards a critical political economy of China and Africa. Development and Change, 44 (6), 1255-1272. 
Murton, G., \& Lord, A. (2020). Trans-Himalayan Power Corridors: Infrastructural Politics and China's Belt and Road Initiative in Nepal. Political Geography. doi:

10.1016/j.polgeo.2019.102100.

Mohan, G. \& Urban, F. (2019). China and Global Resources. In T. Shaw, L. Mahrenbach, R. Modi, \& Y-C. X (Eds), The Palgrave Handbook of Contemporary International Political Economy (pp. 245-61). London: Palgrave Macmillan.

National Development and Reform Commission (2015, March 28). Vision and Actions on Jointly Building the Silk Road Economic Belt and 21st Century Maritime Silk Road. Retrieved from http://en.ndrc.gov.cn/newsrelease/201503/t20150330_669367.html.

Narins, T. P., and Agnew, J. (2019). Missing from the Map: Chinese Exceptionalism, Sovereignty Regimes and the Belt Road Initiative. Geopolitics. doi: 10.1080/14650045.2019.1601082

The Nation (2016, August 29). CPEC “game-changer” for Pakistan, 'fate-changer' for region: PM. Retrieved from https://nation.com.pk/29-Aug-2016/cpec-gamechanger-for-pakistan-fate-changer-for-region-pm.

Neilson, B. (2014). Zones: beyond the logic of exception? Concentric: Literary and Cultural Studies, 40 (2), 11-28.

The New Indian Express (2017, May 13). China to invest $\$ 50$ billion to develop Indus River Cascade: Report. Retrieved from http://www.newindianexpress.com/world/2017/may/13/china-to-invest50-billion-to-develop-indus-rivercascade-report-1604407.html.

The News (2017, January 19). China Rebuts Modi Criticism of CPEC. Retrieved from https://www.thenews.com.pk/print/180272-China-rebuts-Modi-criticism-ofCPEC.

Thrift, N. (1996). Spatial Formations. London: Sage.

OECD (2016). Foreign Direct Investment Statistics: Data, Analysis and Forecasts 2016. Retrieved from http://www.oecd.org/corporate/mne/statistics.htm.

Olds, K., \& Yeung, H. W.-C. (1999). (Re) shaping 'Chinese' business networks in a globalising era. Environment and Planning D: Society and Space, 17(5), 535-555.

Ong, A. (2004). The Chinese Axis: zoning technologies and variegated sovereignty. Journal of East Asian Studies, 4 (1), 69-96.

Overholt, W. H. (2015). Posture Problems Undermining One Belt, One Road and the US Pivot. Global Asia, 10 (3), 16-21.

Page, J. (2014, November 9). China Sees Itself at Center of New Asian Order. The Wall Street Journal. Retrieved from https://www.wsj.com/articles/chinas-new-traderoutes-center-it-on-geopolitical-map-1415559290.

Pan, S. Y., and Lo, J. T.-Y. (2017). Re-conceptualizing China's rise as a global power: a neo-tributary perspective. The Pacific Review, 30 (1), 1-25.

Park, B.-G. (2013). State Rescaling in Non-Western Contexts. International Journal of Urban and Regional Research, 37 (4), 1115-1122.

Qureshi, N. M. (2015, September). Critical Analysis of China Pakistan Economic Corridor. Eurasia Review. Retrieved from https://www.eurasiareview.com/22092015-critical-analysis-of-china-pakistaneconomic-corridor-oped/. 
The Research and Information System for Developing Countries (2017, May 24). Launch of Asia Africa Growth Corridor Vision Document. Retrieved from https://www.ris.org.in/launch-asia-africa-growth-corridor-vision-document.

Roberts, S., Secor, A., \& Sparke, M. (2003). Neoliberal Geopolitics. Antipode, 35 (5), 886-897.

Schindler, S., and Kanai, J. M. (2019). Getting the Territory Right: Infrastructure-Led Development and the Re-Emergence of Spatial Planning Strategies. Regional Studies. doi: 10.1080/00343404.2019.1661984

Schouten P., Stepputat, F., \& Bachmann, J. (2019). 'States of circulation: Logistics off the beaten path', Environmental Planning D: Society and Space, 37(5), 779-793.

Shen, G. J., \& Chen B.K. (2017). Zombie firms and over-capacity in Chinese manufacturing. China Economic Review, 44 (July), 327-342.

Sheppard, E., \& McMaster, R. (Eds.). (2004). Scale and Geographic Inquiry. Blackwell: Oxford.

Singh, G. A. (2016). China's soft power projection across the oceans. Maritime Affairs: Journal of the National Maritime Foundation of India, 12 (1), 25-37.

Singh, K. (2015). China Wants to Talk OBOR with India. Sunday Guardian. Retrieved from http://www.sundayguardianlive.com/news/2216-china-wants-talkobor-india.

South China Morning Post (2017, October 10). Being Xi Jinping: the difficult art of juggling growth and control after China's Communist Party Congress. Retrieved from http://www.scmp.com/news/china/policiespolitics/article/2114471/being-xi-jinping-difficult-art-juggling-growth-and.

Steinberg, P.E. (2001). The Social Construction of the Ocean. Cambridge, UK: Cambridge University Press.

Strandsbjerg, J. (2010). Territory, Globalization and International Relations: the cartographic reality of space. London: Palgrave.

Summers, T. (2016). China's 'New Silk Roads': sub-national regions and networks of global political economy. Third World Quarterly, 37 (9), 1628-1643.

Summers, T. (2019). The belt and road initiative in Southwest China: responses from Yunnan province. The Pacific Review. doi: 10.1080/09512748.2019.1653956

Su, X. (2013). From Frontier to Bridgehead: Cross-border Regions and the Experience of Yunnan, China. International Journal of Urban and Regional Research, 37 (4), 1213-32.

$\mathrm{Su}, \mathrm{X}$. (2014). Multi-scalar regionalization, network connections and the development of Yunnan Province, China. Regional Studies, 48(1), 91-104.

Sukhankin, S. (2018). 'China's “Polar Silk Road” versus Russia’s Arctic Dilemmas', Eurasia Daily Monitor, 15 (159).

Summers, T. (2016). China's 'New Silk Roads': sub-national regions and networks of global political economy. Third World Quarterly, 37 (9), 1628-1643.

Sun, Y. (2017, May 17). Gaiceng Zhinang Xu Shanda, jiemi Zhongguo Yidai Yilu lailong qumai [Higher level advisor Xu Shanda: decoding the One Belt-One Road].

Fenghuang Dacankao. Retrieved from

http://news.ifeng.com/dacankao/xushanda1/1.shtml.

Syed, B.S. (2016, September 19). Civil-military differences hold up CPEC security plan. Dawn. Retrieved from https://www.dawn.com/news/1284724. 
Swyngedouw E. (1997). Neither global nor local: 'glocalization' and the politics of scale. In K. Cox (Ed), Spaces of Globalization (pp. 137-66). New York: Guilford Press.

Swyngedouw, E. (2004). Scaled geographies: Nature, place, and the politics of scale. In E. Sheppard \& R.B. McMaster (Eds), Scale and Geographic Inquiry: Nature, society, and method (pp.129-153). Oxford: Blackwell.

Tang, F. (2016, December 1). China's bid to cut production overcapacity in heavy industries 'losing steam', survey suggests. South China Morning Post. Retrieved from https://www.scmp.com/news/china/economy/article/2050705/chinas-bid-cutproduction-overcapacity-heavy-industries-losing.

Tharoor, S. (2015) China's Silk Road Revival-and the Fears It Stirs-Are Deeply Rooted in the Country's History. New Perspectives Quarterly, 32 (1), 18-21.

Tooze, A. (2018). Crashed: How a decade of financial crises changed the world. Penguin. Tuathail, G. Ó. (2000). The Postmodern Geopolitical Condition: states, statecraft, and security at the millennium. Annals of the Association of American Geographers, 90 (1), 166-178.

Tuathail, G. Ó., Dalby, S. \& Routledge, P., (Eds). (2006). The Geopolitics Reader (2nd ed.). New York: Routledge.

Turner, B. S. (2007). The Enclave Society: Towards a Sociology of Immobility. European Journal of Social Theory, 10 (2), 287-303.

Vukovich, D. F. (2012). China and Orientalism: Western Knowledge Production and the P.R.C. Routledge.

Wagner, H. (2017). The Building Up of New Imbalances in China: the dilemma with 'rebalancing'. International Economics and Economic Policy, 14 (4), 701-722.

Wang, H. (2016). 'Dangdai zhongguo lishijubian zhong de Taiwan wenti: cong 2014 nian de "taiyanghua yundong" tanqi' [The Taiwan Issue in the Great Historical Transformation of Contemporary China: Starting from the 'Sunflower Movement' in 2014] Wenhua Zongheng [Beijing Cultural Review], 1, 70-79.

Wang, Y. W. (2015, November 28). Misconceptions about the Belt and Road. China Daily. Retrieved from http://usa.chinadaily.com.cn/opinion/2015-

11/28/content_22525643.htm.

Wang, Y. W. (2016). The Belt and Road: What Will China Offer the World in Its Rise, Beijing: New World Press.

Williams, J., Robinson, C. \& Bouzarovski S. (2019). China's Belt and Road Initiative and the emerging geographies of global urbanisation. The Geographical Journal. doi: $10.1111 /$ geoj.12332

Wilson, J., and Bayón, M. (2016). 'Black Hole Capitalism', City, 20(3), 350-367.

World Bank (2017). Pakistan. Retrieved from https://data.worldbank.org/country/pakistan.

Wu, F. L. (2016). China's Emergent City-region governance: a new form of state spatial selectivity through state-orchestrated rescaling. International Journal of Urban and Regional Research, 40 (6), 1134-1151.

Wu, Y. M. (2017). Lianjie 'dai' yu 'lu' de sanda langdao [The Three Major Corridors Connecting the Belts and Roads]. Unpublished report.

Xi, J. P. (2016, April 30). Jiejian lishijingyan chuanxin hezuolinian, rang 'yidaiyilu' jianshe tuidong geguo gongtong fazhan [Learn from Historical Experiences, Innovate Cooperative Ideas, Let the Construction of OBOR Promote Co- 
development of All Countries]. Retrieved from http://www.gov.cn/xinwen/201604/30/content_5069523.htm.

Xia, L.I. (2004). Spatio-temporal analysis of land use patterns in the development corridor of the Pearl River Delta in 1988-1997. Journal of Natural Resources, 19(3), 307315.

Xia, X. (2017, May 8). 'Yidai yilu' changyi sannianduolai qude huihuang chengjiu [The BRI has made splendid achievements in the past three years] Jingjicankaobao [Economic Information Daily]. Retrieved from http://jjckb.xinhuanet.com/201705/08/c_136264500.htm.

Xinhua (2017, December 25). Yidai yilu guojia you naxie? [Which are the One Belt and One Road countries?]. Retrieved from http://silkroad.news.cn/2017/1225/76186.shtml.

Xinhua (2019, October 9). Xi Jinping huijia bajisitan zongli yimulan han [Xi Jinping meets Prime Minister of Pakistan Imran Khan]. Retrieved from http://www.gov.cn/xinwen/2019-10/09/content_5437560.htm.

Yang, C. (2014). The Eurasian moment in global politics: a comparative analysis of great power strategies for regional integration. In P. Dutkiewicz \& R. Sakwa (Eds), Eurasian Integration: The View from Within (pp. 274-289). Routledge.

Yang, F. (2015). 'Jiemi "guoji channeng hezuo" de lailongqumai" [Decoding the Causes of 'International Capacity Cooperation'], 13 December; accessed at http://politics.people.com.cn/n1/2015/1213/c1001-27922214.html, 25 May 2016.

Yao, S. M., Chen, S., Wu, J. N., Zhang, Y., \& Chan, R. C. K. (2009). Spatial Expansion Patterns of Chinese Big Cities: the case of Suzhou. Scientia Geographica Sinica, 29 (1), 15-21.

Yeh, E. T. (2016). Introduction: The geoeconomics and geopolitics of Chinese development and investment in Asia. Eurasian Geography and Economics, 57 (3), 275-285.

Zeng, X. H. (2016). Yidaiyilude diyuanzhengzhi xiangxiang yu diqu hezuo [The Geopolitical Imagination of OBOR and Regional Cooperation], Shijie Jingji yu Zhengzhi [World Politics and Economy], 1, 46-71.

Zhang, X. (2017). Chinese Capitalism and the Maritime Silk Road: a world-systems perspective. Geopolitics, 22 (2), 310-331.

Zimmerman T. (2015). The New Silk Roads: China, The U.S., and the Future of Central Asia. Center on International Cooperation. Retrieved from http://cic.nyu.edu/sites/default/files/zimmerman_new_silk_road_final_2.pdf. 